\title{
Seed Yield and Yield Contributing Traits of Okra As Influenced By Fruit Positions and Fruit Retention Loads
}

\author{
Sagar Kumar Sharma* , C.P. Sachan, C.L. Maurya, \\ Udai Singh Chaudhary and Parikshit Singh
}
Department of Seed Science and Technology, CSA University of Agriculture \& Technology, Kanpur, Uttar Pradesh, India

*Corresponding author

\begin{abstract}
A B S T R A C T
In order to evaluate the influence of fruit positions and fruit retention loads on seed yield and yield contributing traits of okra, an experiment was conducted in 2016 at Vegetable Research farm, Kalyanpur by using Factorial Randomized Block Design with three

\section{Keywords}

Okra, Seed yield, Fruit positions and fruit retention loads

Article Info

Accepted:

20 August 2018

Available Online:

10 September 2018 replications. The okra variety, Arka Anamika was tested with 12 treatment combinations (consisted of two fruit retention loads as factor - I and six fruit positions as factor - II). Observations were recorded on seed yield and yield contributing traits. Results revealed the significant variation between factors and their levels. Significantly highest values for number of fruits/ plant, fruit length $(\mathrm{cm})$, number of seeds/ fruit and green fruit yield were recorded in $\mathrm{R}_{1}$ (Retention of fruits borne on different nodes for seed purpose and harvesting remaining fruits for vegetable purpose) fruit retention load over $\mathrm{R}_{2}$ ((Retaining all fruits). Among the fruit positions, $\mathrm{P}_{1}$ (From fruits borne on 1-3 nodes) position recorded significantly maximum values for most of the yield and yield contributing traits. Thus, it is concluded from the research work that for harvesting highest fruit length, number of fruits per plant, number of seeds per fruit and green fruit yield, the treatment combination $\mathrm{R}_{1} \mathrm{P}_{1}$ (Retention of fruits borne on 1-3 nodes for seed purpose and harvesting remaining fruits for vegetable purpose) and for getting highest seed yield, the treatment combination $\mathrm{R}_{1} \mathrm{P}_{6}$ (Retention of all fruits for seed purpose) may be adopted.
\end{abstract}

\section{Introduction}

In India, okra (Abelmoschus esculentus L. Moench) is one of the most important fresh vegetable crop grown in about 528.4 thousand ha area producing 6146.0 thousand tonnes green fruit under temperate to tropical regions (Horticultural statistics at a glance, 2017, DAC, GOI). In intensive commercial farming systems, seed is the most critical input that grossly determines expected returns from all other agricultural inputs. Hence, there has been growing demand for production and distribution of quality vegetable seeds. Naik and Srinivas (1984) reviewed the importance of appropriate agronomic practices, climatic conditions \& season, adequate pollination and seed set, effect of fruit position, maturity and seed extraction methods on quality of developing seeds. Okra is one of the most important vegetable crops grown for its green fruits for vegetable purpose. There is a greater 
demand of its seeds from growers. Various factors influence the seed yield in okra among which position of fruit and green fruit pickings are of great significance. Green fruit pickings promote fruit development and higher yield as it stimulates okra fruits to produce more number of fruits per plant. Quality of seed often determines the stability of yield in vegetable crops. Nucleus seeds which are of high quality should therefore be collected from fruits harvested at physiological maturity. In indeterminate flowering plants, the fruits may vary widely in seed maturity depending on the nodal positions of the seed pod.

Quality seed pays not cost, the utility of the secondary inputs directly concerned with primary input as a seed. Among the vegetable crops in which green fruits are directly used as a vegetable, the scarcity of quality seed has always been observed. Okra being an indeterminate in nature it has peculiar fruiting behaviour. The next flowering and fruiting does not take place till previous fruits are not completed. Being it, the maturity of fruits happens in different interval and directly influences the source to sink system. The present investigation has been taken to identify the judicious system of distribution of photosynthates among the fruit vis-a-vis to seed. Plucking and retention of the green fruits at different nodes could be most effective not only to harness highest vigorous seed with optimum seed yield but also fetch the purpose of green fruit marketing.

\section{Materials and Methods}

The present investigation was carried out in Factorial Randomized Block Design with three replications. The okra variety Arka Anamika was tested with 12 treatment combinations (consisted of two fruit retention loads as factor - I and six fruit positions as factor - II) during Kharif 2016 at Vegetable research Farm, Kalyanpur, C.S. Azad university of Agriculture and Technology, Kanpur. The observations were recorded on days to flower initiation, fruit length $(\mathrm{cm})$, number of fruits/plant, number of seeds/fruit, green fruit yield (kg/ha) and seed yield $(\mathrm{kg} / \mathrm{ha})$. The data analyzed statistically and presented in Table 2 and 3.

\section{Results and Discussion}

The fruit positions and fruit retention loads showed significant difference on seed yield and yield contributing traits of okra.

\section{Influence of fruit positions and fruit retention loads on growth parameters}

On perusal of the Table 2, it is clear that fruit length, number of fruits/ plant and number of seeds per fruit recorded significant differences due to fruit positions and fruit retention loads while, the days to flower initiation was nonsignificant. The fruit retention load $R_{1}$ (Retention of fruits borne on different nodes for seed purpose and harvesting remaining fruits for vegetable purpose) recorded higher growth attributes compared to $\mathrm{R}_{2}$ load (Retaining all fruits). Significantly maximum fruit length $(10.05 \mathrm{~cm})$, number of fruits/plant (24.16) and number of seeds per fruit (53.29) were recorded in $\mathrm{R}_{1}$ fruit retention load over $\mathrm{R}_{2}$ fruit retention load. Hence, the $\mathrm{R}_{1}$ fruit retention load can be considered as the best to achieve higher growth response in okra crop. This might be due to the fact that the enhanced food materials translocated towards the site of new pod formation and development. The results are in accordance with the findings of Mohammadi et al., (2015), Moniruzzaman and Quamruzzaman (2009), Khan and Jaiswal (1988) and Grewal et al., (1972).

The days to flower initiation, fruit length, number of fruits per plant and number of seeds per fruit differed significantly due to the fruit 
positions. Among the different fruit positions, $\mathrm{P}_{1}$ (collection of seeds from fruits borne on 13 nodes) recorded significantly minimum days to flower initiation (40.57) and maximum number of fruits per plant (23.00) and fruit length $(11.15 \mathrm{~cm})$ while, lowest was recorded in $\mathrm{P}_{3}$ (From fruits borne on above $8^{\text {th }}$ node) $(8.38 \mathrm{~cm})$.

$P_{1}$ (59.43) fruit position recorded significantly maximum number of seeds followed by $\mathrm{P}_{2}$ (From fruits borne on 4-8 nodes) (56.90) and $\mathrm{P}_{4}$ (From fruits borne on 1-8 nodes) (54.52) and minimum was in $\mathrm{P}_{3}$ (From fruits borne on above $8^{\text {th }}$ node) (42.18). Yadav et al., (2007) reported higher values of seeds per fruit from lower positions of plant closely followed by middle position and significantly lower values were observed in seeds of upper position fruits. These findings are in line with those of Prabhakar et al., (2003), Bhatt and Srinivas
Rao (1998), Rao et al., (2004) and Verma et al., (1998).

Influence of fruit positions and fruit retention loads on yield parameters

On perusal of data given in Table 3, it is clear that significant difference in fruit yield was found due to the fruit positions. The $\mathrm{P}_{1}$ fruit position recorded maximum $(3669.00 \mathrm{Kg} / \mathrm{ha})$ green fruit yield followed by $\mathrm{P}_{2}$ (From fruits borne on $4-8$ nodes) $(3173.00 \mathrm{Kg} / \mathrm{ha})$ and $\mathrm{P}_{3}$ (From fruits borne on above $8^{\text {th }}$ nodes) $(2492.00 \mathrm{Kg} / \mathrm{ha})$ while the minimum was in $\mathrm{P}_{5}$ $(923.00 \mathrm{Kg} / \mathrm{ha})$. The increase in green fruit yield in case of $\mathrm{P}_{1}$ (collection of seeds from 13 nodes) may be due to the higher number of green fruits harvested for vegetable purpose. As far as the fruit retention loads are concerned, green fruits were not harvested in $\mathrm{R}_{2}$ fruit retention load (Retaining all fruits).

Table.1 Weekly weather parameters recorded during crop growth of okra in kharif 2016

\begin{tabular}{|c|c|c|c|c|}
\hline \multirow[t]{2}{*}{ Standard week } & \multicolumn{2}{|c|}{ Temperature $\left({ }^{0} \mathrm{C}\right)$} & \multirow{2}{*}{$\begin{array}{c}\text { Relative } \\
\text { Humidity (\%) }\end{array}$} & \multirow[t]{2}{*}{ Rainfall (mm) } \\
\hline & Max. & Min. & & \\
\hline $22-28$ July & 31.3 & 25.4 & 83 & 42.4 \\
\hline 29 July- 4 Aug & 33.2 & 26.3 & 79 & 5.3 \\
\hline $5-11$ & 33.0 & 25.8 & 84.5 & 112.6 \\
\hline $12-18$ & 34.3 & 26.1 & 77 & 1.0 \\
\hline $19-25$ & 32.9 & 25.5 & 84 & 89.2 \\
\hline 26 Aug- 01 Sep & 33.2 & 25.2 & 82.4 & 2.2 \\
\hline $2-8$ & 35.1 & 25.5 & 77.5 & 3.6 \\
\hline $9-15$ & 36.2 & 25.7 & 48.16 & 0 \\
\hline $16-22$ & 33.7 & 25.3 & 85 & 34.5 \\
\hline $23-29$ & 34.2 & 23.3 & 75 & 0 \\
\hline 30 Sep - 06 Oct & 35.3 & 24.3 & 69 & 0 \\
\hline $7-13$ & 35.8 & 22.9 & 63.5 & 0 \\
\hline $14-20$ & 35.9 & 19.3 & 77 & 0 \\
\hline $21-27$ October & 34.3 & 15.7 & 58 & 0 \\
\hline
\end{tabular}


Table.2 Influence of fruit positions and fruit retention loads on growth parameters of okra

\begin{tabular}{|c|c|c|c|c|c|c|c|c|c|c|c|c|}
\hline \multirow[t]{2}{*}{ Treatments } & \multicolumn{3}{|c|}{ Days to flower initiation } & \multicolumn{3}{|c|}{ Fruit length(cm) } & \multicolumn{3}{|c|}{ Number of fruits /plant } & \multicolumn{3}{|c|}{ Number of seeds/ fruit } \\
\hline & $\mathbf{R}_{1}$ & $\mathbf{R}_{2}$ & Mean & $\mathbf{R}_{1}$ & $\mathbf{R}_{2}$ & Mean & $\mathbf{R}_{1}$ & $\mathbf{R}_{2}$ & Mean & $\mathbf{R}_{1}$ & $\mathbf{R}_{2}$ & Mean \\
\hline $\mathbf{P}_{1}$ & 40.49 & 40.66 & 40.57 & 11.40 & 10.91 & 11.15 & 33.00 & 13.00 & 23.00 & 61.39 & 57.47 & 59.43 \\
\hline $\mathbf{P}_{2}$ & 41.02 & 41.08 & 41.05 & 10.44 & 9.82 & 10.13 & 27.00 & 12.00 & 19.50 & 57.81 & 55.99 & 56.90 \\
\hline $\mathbf{P}_{3}$ & 42.64 & 42.14 & 42.39 & 8.83 & 7.94 & 8.38 & 28.66 & 14.00 & 21.33 & 45.05 & 39.31 & 42.18 \\
\hline $\mathbf{\mathbf { P } _ { 4 }}$ & 40.75 & 40.69 & 40.72 & 10.12 & 9.71 & 9.91 & 23.33 & 13.00 & 18.16 & 55.93 & 53.12 & 54.52 \\
\hline $\mathbf{P}_{5}$ & 42.38 & 42.21 & 42.29 & 9.98 & 9.16 & 9.57 & 19.00 & 14.00 & 16.50 & 50.36 & 47.36 & 48.86 \\
\hline Comparing & \multicolumn{2}{|c|}{ CD at $5 \%$} & S.E. (d) & \multicolumn{2}{|c|}{ CD at $5 \%$} & S.E. (d) & \multicolumn{2}{|c|}{ CD at $5 \%$} & S.E. (d) & \multicolumn{2}{|c|}{ CD at $5 \%$} & S.E. (d) \\
\hline $\mathbf{R}$ & \multicolumn{2}{|c|}{ N.S. } & 0.26 & \multicolumn{2}{|c|}{0.49} & 0.23 & \multicolumn{2}{|c|}{3.67} & 1.81 & \multicolumn{2}{|c|}{0.67} & 0.33 \\
\hline $\mathbf{P}$ & \multicolumn{2}{|c|}{0.94} & 0.45 & \multicolumn{2}{|c|}{0.86} & 0.41 & \multicolumn{2}{|c|}{2.26} & 1.12 & \multicolumn{2}{|c|}{1.17} & 0.58 \\
\hline
\end{tabular}

Table.3 Influence of fruit positions and fruit retention loads on yield parameters of okra

\begin{tabular}{|c|c|c|c|c|c|c|}
\hline \multirow[t]{2}{*}{ Treatments } & \multicolumn{3}{|c|}{ Green fruit yield (Kg/ha.) } & \multicolumn{3}{|c|}{ Seed yield (Kg/ha.) } \\
\hline & $\mathbf{R}_{1}$ & $\mathbf{R}_{2}$ & Mean & $\mathbf{R}_{1}$ & $\mathbf{R}_{2}$ & Mean \\
\hline $\mathbf{P}_{1}$ & 3669.00 & $0.00 *$ & 3669.00 & 204.00 & 191.00 & 197.50 \\
\hline $\mathbf{P}_{2}$ & 3173.00 & 0.00 & 3173.00 & 463.00 & 433.00 & 448.00 \\
\hline $\mathbf{P}_{3}$ & 2492.00 & 0.00 & 2492.00 & 181.00 & 163.00 & 172.00 \\
\hline $\mathbf{P}_{4}$ & 1751.00 & 0.00 & 1751.00 & 661.00 & 614.00 & 637.50 \\
\hline $\mathbf{P}_{5}$ & 923.00 & 0.00 & 923.00 & 346.00 & 322.00 & 334.00 \\
\hline $\mathbf{P}_{6}$ & $0.00 *$ & 0.00 & 0.00 & 802.00 & 784.00 & 793.00 \\
\hline Mean & 2401.60 & 0.00 & 2401.60 & 442.83 & 417.83 & 430.33 \\
\hline Comparing & \multicolumn{2}{|c|}{ CD at $5 \%$} & S.E. (d) & \multicolumn{2}{|c|}{ CD at $5 \%$} & S.E. (d) \\
\hline $\mathbf{R}$ & \multicolumn{2}{|c|}{--------- } & --------- & \multicolumn{2}{|c|}{10.26} & 4.94 \\
\hline $\mathbf{P}$ & \multicolumn{2}{|c|}{436.30} & 210.05 & \multicolumn{2}{|c|}{17.77} & 8.57 \\
\hline
\end{tabular}

*In $\mathrm{R}_{2}$ and $\mathrm{P}_{6}$, green fruits were not harvested for vegetable purpose. 
Seed yield exhibited significant differences due to fruit retention loads. Due to the superiority in growth parameters, the fruit retention load $R_{1}$ recorded significantly highest seed yield $(442.83 \mathrm{~kg} / \mathrm{ha})$ over the $\mathrm{R}_{2}$ fruit retention load $(417.83 \mathrm{~kg} / \mathrm{ha})$. Seed yield differed significantly due to fruit positions. The $\mathrm{P}_{6}$ fruit position recorded significantly maximum $(793.00 \mathrm{~kg} / \mathrm{ha})$ seed yield followed by $\mathrm{P}_{4}\left(637.50 \mathrm{Kg} / \mathrm{ha}\right.$.) and $\mathrm{P}_{2}(448.00$ Kg./ha.) while, minimum (172 kg/ha) seed yield was recorded in $\mathrm{P}_{3}$ fruit position. The increase in seed yield in case of $\mathrm{P}_{6}$ (collection of seeds from all fruits) may be due to the higher number of fruits considered for collection of seeds. These findings are in line with the findings of Madalgeri, (1979), Nataraj (1988) Khan and Jaiswal (1988), Deshmukh and Tayde (1986), Moniruzzaman and Quamruzzaman (2009), Kumari et al., (2013) and Bhanuje and Raikar (2016).

\section{Fruit retention (R)}

$\mathrm{R}_{1}$ : Retention of fruits borne on different nodes for seed purpose \& harvesting remaining fruits for vegetable purpose.

$\mathrm{R}_{2}$ : Retaining all fruits.

\section{Collection of seeds from different fruit positions (P)}

$\mathrm{P}_{1}$ : From fruits borne on 1-3 nodes.

$\mathrm{P}_{2:}$. From fruits borne on 4-8 nodes.

$\mathrm{P}_{3}$ : From fruits borne on above $8^{\text {th }}$ nodes.

$\mathrm{P}_{4}$ : From fruits borne on 1-8 nodes.

$\mathrm{P}_{5 \text { : }}$ From fruits borne on $4^{\text {th }}$ node and onwards. $\mathrm{P}_{6:}$ From all nodes.

It is concluded from the research work that for harvesting highest fruit length, number of fruits per plant, number of seeds per fruit and green fruit yield, the treatment combination $\mathrm{R}_{1} \mathrm{P}_{1}$ (Retention of fruits borne on 1-3 nodes for seed purpose and harvesting remaining fruits for vegetable purpose) and for getting highest seed yield, the treatment combination $\mathrm{R}_{1} \mathrm{P}_{6}$ (Retention of all fruits for seed purpose) may be adopted.

\section{Acknowledgement}

This study has been supported by Department of Science and Technology, Ministry of Science and Technology, New Delhi, India.

\section{References}

Anonymous (2017) Horticultural Statistics at a glance, DAC, GOI pp 150.

Bhanuje, T., and Raikar S. D. (2016) Influence of fruit load and green fruit pickings on seed quality of brinjal. Res. Environ. Life Sci. 9(11):1313-1315.

Bhatt, R. M. and Srinivasa Rao, N. K. (1998) Germination response to fruit position and temperature in okra (Abelmoschus esculentus L.). Indian J. Hort., 55(1):81-84.

Deshmukh, S. N. and Tayde, G. S. (1986). Yield and quality of okra seed as affected by fruit number. PKV Res. J., 10(1): 66-68.

Grewal, B. S., Nandpuri, K. S. and Kumar, J. C., (1972) Effect of date of sowing, spacing and picking of green pod on seed production of okra. Punjab Hort. J., 12: 248-254.

Khan, A. R. and Jaiswal, R. C., (1988). Effect of nitrogen, spacing and green fruit picking on the seed production of okra [Abelmoschus esculentus (L.) Moench]. Veg. Sci., 15(1): 8-14.

Kumari, S., Singh, S.P. and Kumar D. (2013) Effect of fruit number on seed yield and quality of okra [Abelmoschus esculentus (L.) Moench]. The Asian Journal of Horticulture 8(1): 106-109.

Madalageri, S. (1979) A comparative study of clusterbean as grain and vegetable crop. Madras Agric. J., 51:8-12. 
Mohammadi, G., Khah E., Petropoulos S. A. and Chachalis, D. (2015) Effect of fruit load on pod and seed characteristics of okra (Abelmoschus esculentus L.) Fascicula Biologie Tom. XXII., 1: 2632.

Moniruzzaman, M. and Quamruzzaman A.K.M. (2009) Effect of Nitrogen Levels and Picking of Green Fruits on the Fruit and Seed Production of Okra (Abelmoschus esculentus (L.) Moench). J Agric Rural Dev. 7(1\&2): 99-106.

Naik, I B and Srinivas, K. (1984). Seed production of vegetdbles - a review. 1 Solanaceous crops. Agricul. Rev. 10: 109-123.

Nataraj, S. E., (1988) Effect of nitrogen levels and green fruit picking on seed yield and quality of okra [Abelmoschus esculentus (L.) Moench]. M.Sc. (Agri) Thesis, Univ. Agric. Sci., Dharwad, Karnataka (India).
Prabhakar, R. S., Hegde, D. M., Srinivas, K. and Doijode, S. D., (2003) Seed quality and productivity of okra in relation to nodal position of pod. South Indian Hort. J., 12: 115-118.

Rao, R.G. S., Singh, P M., Singh, B Pandey, A. K. and Mathura Rai, (2004) Seed germinability and vigour as influenced by fruit position, season and gravity separation in okra (Abelmoschus esculentus L. Moench). Veg. Sci., 31, p. 2.

Verma, O. P., Singh, P. V. and Kushwaha, G. D., (2004) Influence of the order of capsule on seed content and its quality in okra (Abelmoschus esculentus). Seed Res. (New Delhi), 26: 178-179.

Yadav, S. K. and Dhankhar, B. S. (2007) Seed production and quality of okra [Abelmoschus esculentus (L.) moench] cv. Varsha Uphar as affected by sowing time and position of fruit on plant. Seed Res., 23(1):47-51.

\section{How to cite this article:}

Sagar Kumar Sharma, C.P. Sachan, C.L. Maurya, Udai Singh Chaudhary and Parikshit Singh. 2018. Seed Yield and Yield Contributing Traits of Okra As Influenced By Fruit Positions and Fruit Retention Loads. Int.J.Curr.Microbiol.App.Sci. 7(09): 3026-3031. doi: https://doi.org/10.20546/ijcmas.2018.709.377 